\title{
Market composition and direction of trade of marine products exports from India
}

\author{
ANAND MISHRA AND R.A. YELEDHALLI
}

Received : 14.06.2017; Revised : 23.08.2017; Accepted : 07.09.2017

\begin{abstract}
India is a major supplier of marine products in the world. Marine products are major contributor in the Indian agricultural exports as a whole. In the financial year 2014-15 the marine products exports accounted for $14.54 \%$ (Rs. 33441.61 crore ) of the total agricultural exports (Rs. 2,29,996 crore) which shows the increasing importance of marine products exports in the total Indian agricultural exports portfolio. The present study aims to explore the market composition and direction of trade of marine products exports from India. The yearly data on export quantity, value and US \$ terms have been compiled from Marine Products Export Development Authority (MPEDA) website for a period of 14 years (2001-02 to 2014-15) and being analysed with appropriate tools. The results showed that Japan, USA, European Union, China, South East Asia and Middle East are the major destinations for Indian marine products South East Asia was the largest market for Indian marine products. Whereas, USA claimed the largest share in terms of the value of exported commodities because of high valued marine products. Japan has reported to be the most unstable destination as far as Indian marine product exports are concerned whereas it used to be a major exports destination for Indian marine products in recent past. The decrease in exports to countries like Japan and China may be related to the inadequate infrastructure, processing, packaging and grading facilities and lack of proper attention towards hygienic practices. Therefore, an increasing need for compliance to SPS measures has been realised for which conscious efforts and investment in raising our compliance standards are inevitable.
\end{abstract}

KEY WORDS : Market composition, Direction of trade, Marine products, Major supplier

How to cite this paper : Mishra, Anand and Yeledhalli, R.A. (2017). Market composition and direction of trade of marine products exports from India. Internat. J. Com. \& Bus. Manage, 10(2) : 146-149, DOI: 10.15740/HAS/IJCBM/10.2/146-149.

\section{MEMBERS OF THE RESEARCH FORUM}

Correspondence to:

ANAND MISHRA, Department of Agribusiness Management, University of Agricultural Sciences, DHARWAD (KARNATAKA) INDIA

Email: anandmishra6@gmail.com

\section{Authors' affiliations:}

R.A. YELEDHALLI, Department of Agribusiness Management, University of Agricultural Sciences, DHARWAD (KARNATAKA) INDIA 